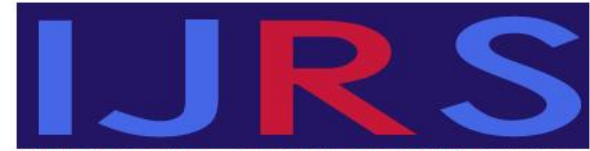

Hipatia Press

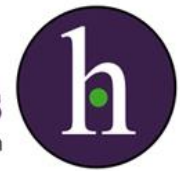

Instructions for authors, subscriptions and further details:

http://ijrs.hipatiapress.com

\title{
"We are achieving this... Eliminating the violence and making us all Friends". The power of friendships to generate peaceful coexistence in Sant Roc (Badalona)
}

Beatriz Villarejo-Carballido ${ }^{1}$, Carme García Yeste ${ }^{2}$, Maria del Mar Ramis ${ }^{3}$, and Laura Ruiz-Eugenio ${ }^{3}$

1) Universidad de Deusto. Spain

2) Universitat Rovira i Virgili. Spain

3) Universitat de Barcelona. Spain

Date of publication: March $15^{\text {th }}, 2020$

Edition period: March 2020 - September 2020

To cite this article: Villarejo-Carballido, B., García Yeste, C., Ramis, M., and Ruiz-Eugenio, L. (2020). "We are achieving this... Eliminating the violence and making us all Friends". The power of friendships to generate peaceful coexistence in Sant Roc (Badalona). International Journal of Roma Studies, 2(1), 64-87. doi: 10.17583/ijrs.2020.5227

To link this article: http://dx.doi.org/10.17583/ijrs.2020.5227

PLEASE SCROLL DOWN FOR ARTICLE

The terms and conditions of use are related to the Open Journal System and to Creative Commons Attribution License (CCAL). 


\title{
"We are achieving this... \\ Eliminating the violence and
}

\section{making us all Friends". The power of friendships to generate peaceful coexistence in Sant Roc (Badalona)}

Beatriz Villarejo-Carballido

Universidad de Deusto

Carme García Yeste

Universitat Rovira i Virgili
Maria del Mar Ramis

Universitat de Barcelona

Laura Ruíz-Eugenio

Universitat de Barcelona

\begin{abstract}
This article analyses the contribution of friendship between members of different cultures to improving peaceful coexistence in a vulnerable neighbourhood. Specifically, it analyses the personal friendship between Said, a member of the Pakistani community, and Tio Antonio, a member of the Roma community, as a turning point in improving the coexistence in a neighbourhood which had been experiencing conflictive situations and clashes between the residents for years, especially between the Roma and the Pakistani communities. This friendship has played a mediating role and served as an example for other friendships between members of the two communities, leading to the creation of a joined organization. This analysis contributes to the existing literature, where the role of personal friendship in the transformation of conflictive intercultural relations into peaceful, constructive ones has barely been explored.
\end{abstract}

Keywords: relationship, intergroup communication, friendship, community, conflict, transformation, neighbourhood, social exclusion 


\section{"Estamos consiguiendo esto... Eliminar la violencia y hacernos todos amigos y amigas". El poder de las amistades para generar una convivencia pacífica en Sant Roc (Badalona)}

Beatriz Villarejo-Carballido

Universidad de Deusto

Carme García Yeste

Universitat Rovira i Virgili
Maria del Mar Ramis

Universitat de Barcelona

Laura Ruíz-Eugenio

Universitat de Barcelona

\section{Resumen}

Este artículo analiza la contribución de la amistad entre miembros de diferentes culturas para mejorar la convivencia pacífica en un vecindario vulnerable. Específicamente, analiza la amistad personal entre Said, un miembro de la comunidad paquistaní, y Tio Antonio, un miembro de la comunidad romaní, como un punto de inflexión para mejorar la convivencia en un vecindario que había estado experimentando situaciones conflictivas y enfrentamientos entre los residentes. durante años, especialmente entre las comunidades romaní y pakistaní. Esta amistad ha jugado un papel mediador y sirvió como ejemplo para otras amistades entre los miembros de las dos comunidades, lo que condujo a la creación de una organización unida. Este análisis contribuye a la literatura existente, donde apenas se ha explorado el papel de la amistad personal en la transformación de las relaciones interculturales conflictivas en relaciones pacíficas y constructivas.

Palabras clave: Relación, comunicación intergrupal, amistad, comunidad, conflicto, transformación, vecindad, exclusión social 


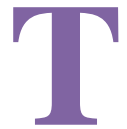
he financial crisis which started in 2008 has led to an increase in the number of people living under the threshold of poverty in the poverty (Eurostat, 2020) and can not afford basic services (Matsaganis \& Leventi, 2014). At the same time, this causes an imbalance in political power and civil liberties (Cole, 2018). Another direct consequence of the financial crisis is that marginal neighbourhoods (Save the Children, 2014). Approximately 33 million people who live in urban areas live in marginal neighbourhoods, and this figure is predicted to increase (UN, 2012). In these neighbourhoods, the lack of opportunities leads the residents to become even more vulnerable (Rusch, Frazier, \& Atkins, 2015; Taylor et al., 2014).

\section{Scene Setting: Neighbourhoods at risk and personal relationships}

In Spain, there are more than 600 neighbourhoods in this situation (Fundación FOESSA \& Caritas España, 2014). Despite having invested considerable economic and social resources in order to overcome the situation of extreme poverty, the standard of living in these neighbourhoods and their inhabitants have not improved. The social downturn in Spain precisely means a clear and constant increase in the proportion of households affected by these economic factors. In disadvantaged neighbourhoods, one out of every four people is affected by extreme exclusion, and exclusion affects $42.8 \%$ of the population living there (Fundación FOESSA \& Caritas España, 2013, 2014; Observatorio de la Vulnerabilidad Urbana, 2011), which perpetuates this situation of poverty.

The groups that are the most vulnerable to exclusion and poverty include immigrants, ethnic minorities and single-parent families (Save the Children, 2014), along with the unemployed (Peruzzi, 2014). The rejection and inequality experienced by immigrants generates socio-spatial segregation due to the difficulty accessing housing (for both economic and racist reasons) (Housing Europe Observatory, 2018). In this vein, according to Gereluk and Race (2007), immigrants and ethnic minorities tend to live in neighbourhoods with high rates of poverty and unemployment, leading to coexistence problems which affect the course of their lives. A situation that gets worse in children and teenagers, Boyle et al. (2019) show that these 
collectives can develop antisocial behaviour and to have higher risk of mental health problems. On the other hand, other authors like Aydin et al. (2013) explain that in neighbourhoods where there is social exclusion for the aforementioned reasons, the occurrence of racist and xenophobic acts is quite common. Mutuma Ruteere, a United Nations (UN) special rapporteur, states that immigrants in some European countries suffer from racism, unemployment, difficulties accessing medical care and segregation in that country (Human Rights Watch, 2014). This is coupled with the fact that having to live in marginal neighbourhoods further excludes them and places constraints in their life opportunities, both personal and work-related, among others (Morrison, 2003). Likewise, according to the European Commission against Racism and Intolerance (ECRI), ethnic minorities also suffer from persistent, systemic racism, which can even be accompanied by violent acts (Nicolae, 2006). This situation occurs in Spain as well, particularly in the peripheral neighbourhoods where feelings of hostility towards foreigners or marginal individuals emerge (Fundación FOESSA \& Caritas España, 2014).

Given this reality, different initiatives are contributing to palliating the socioeconomic difficulties suffered in these contexts and reducing the social exclusion of the population and disturbances caused by coexistence problems (Greene, 2014; Hassan, 2015). Some of these initiatives are targeted at schools with the goal of improving both the educational level and the quality of life of the children in these neighbourhoods. The study by Blank, Melaville, and Shah (2003) contains several examples of programmes, such as the Children's Aid Society and Communities In Schools, among others, which work from the sphere of education to palliate the difficulties that besiege the students with the fewest resources using the support of the community. Also from the sphere of education, Communities In Schools researches schools located in residential slums and contributes to creating schools that take public education to students of different races and economic statuses in an effort to palliate the inequalities they suffer from by living in neighbourhoods with social exclusion (Talaslampi, Jahnukainen, \& Manninen, 2019; Frankenberg \& Orfield, 2007).

Similarly, in Europe and Latin America, the Learning Communities, is one example of a project that is favouring those who suffer from inequalities related to poverty and social exclusion is being conducted in 
the Milagrosa neighbourhood of Albacete, which has a high percentage of the Roma minority. In this context, the transformation of the school through the implementation of successful educational actions and the entire community's engagement in taking important decisions that affect the neighbourhood has contributed to improving peaceful coexistence and the residents' living conditions (García-Carrión, Molina-Luque, \& Molina, 2018; García-Espinel, Santiago-Santiago, \& García-Algar, 2019).

Other studies have shown how in disadvantaged neighbourhoods, the action of groups made up of community members (local, religious and other kinds of organisations) is essential to dealing with the poverty that is concentrated in certain urban areas with severe material deprivation (Saegert, Thompson \& Warren, 2002; Wilson, 1996). When people participate to improve society in general and the lives of others in particular they show that they are beings who do not live just to adapt to events but go further and try to transform difficulties into possibilities (Girbés-Peco et al., 2018; Ramis, 2018). Through the example of Singapore, Ho and Chua (2017) show how in today's contemporary cities, the relationships with and feelings of those with whom we live should be placed in the foreground, shaping cohesive relations that go beyond one's own home or neighbourhood. The community culture evolves through spatial habits and territorial loyalties in which neighbourhoods and the people that occupy them are also crucial. Rebuilding social capital in disadvantaged neighbourhoods takes place by promoting feelings of solidarity and mutual support (Morrison, 2003). Likewise, there is also evidence of the impact that personal friendships in particular can have on improving one's individual reality and the reality of the people in one's milieu (Giner, 2018), as we shall see in the next section.

\section{Friendship and its personal and social effects}

Personal friendship is defined as an affective, voluntary relationship, the most common kind of relationship throughout people's lifetimes (Asher, Parker \& Walker, 1996; Hartup \& Stevens, 1999). This kind of relationship is crucial in social life (Silk, 2003) since it provides a social structure and reinforces and consolidates group mores, attitudes and values, which are the 
ultimate underpinning of individual and collective competence (Blieszner \& Adams, 1992; Hartup, 1999).

As defined by Bukowski, Motzoi, and Meyer (2009), a quality or true friendship entails the "strong, positive affective bonds that exist between two persons and that are intended to facilitate the attainment of socioemotional goals" (p. 218). What lies at the core of this friendship is "egalitarian interactions in which a person is attracted to another who is attracted in return" (p. 218).

Different studies on friendship show that a person who has true friends has better wellbeing (Hartup \& Stevens, 1999), confidence, autonomy (Jones et al., 2014) and happiness (Demir, Simsek, \& Procsal, 2012), and that friendship buffers the effects of crises (Tooby \& Cosmides, 1996) as well as illnesses or injuries (Harper, Dolcini, \& Benhorin, 2014). Likewise, quality friendship among people is beneficial for society in general because it helps prevent social problems like bullying, gender violence and social inequalities, in addition to preventing family risk factors when faced with situations such as low parental supervision and awareness, while also fostering academic improvements in children and youths (Berndt, 1996; Bukowski et al., 2009; Millen, Dorn, \& Luchner, 2019). Studies like Wong (2006) have also found that quality friendship is the foundation for emerging from poverty and inequality, generating networks beyond one's own closest milieu. In a similar vein, Tilly (2012) states that people who suffer from inequalities because they live in disadvantaged environments believe that friends have an incalculable value when dealing with their situation; they also believe that having networks of friends in situations that are not disadvantaged is also essential to deal with barriers to inequality. In a complementary fashion, MacDonald et al. (2005) states that overcoming social exclusion and inequalities are directly related to not having friendships in developed contexts.

On the other hand, different studies show the positive effects of intergroup friendship and have identified doing favours, providing advice and handling conflicts as the types of assistance which friends in different cultures provide (Lee, 2006). Meleady and Vermue (2019) point out that one of the positive aspects of this friendship is the support of the collective actions. Furthermore, friendships between people from different social and cultural groups can influence the attitudes that each group has towards the 
other (Allport, 1954). However, in order for there to be positive attitudes in friendships, certain conditions must be in place, such as a relationship based on equality, shared objectives or institutional support. These conditions make it possible to lower prejudices and stereotypes between groups and for aggressive actions to be reduced (Allport, 1954; Bilge, 2019; Pettigrew \& Tropp, 2008). Quality friendship, that is, the kind based on positive values have also been found to have positive repercussions on the development of social skills and the ability to reach agreement with different people (Ainscow \& Miles, 2009). However, there is little literature related to intergroup and intercultural friendships between adults in vulnerable neighbourhoods and about the impact of this kind of relationship on overcoming conflicts and transforming the milieu. This article seeks to provide new evidence that contributes to covering this gap by studying a story of intercultural friendship which emerged in a disadvantaged context and is improving the lives of people in a situation of social risk.

\section{The case study: The Sant Roc neighbourhood, Tio ${ }^{1}$ Antonio and Said}

The case study took place in one of the most depressed neighbourhoods in the city of Badalona (in Catalonia, Spain), the fourth most populous city in Catalonia (after Barcelona, Hospitalet de Llobregat and Terrassa). The unemployment rate in Badalona was $17.86 \%$, and it is one of the cities in Spain with the lowest quality of life (Ajuntament de Badalona, 2015; OCU, 2012). This neighbourhood has publicly-subsidised housing built in the $1950 \mathrm{~s}$ and $1960 \mathrm{~s}$ in order to relocate people who lived in hand-built shanties with minimal inhabitability conditions, most of whom were Roma. This process, which was done too quickly, caused overcrowding and the lack of decent living conditions, coupled with a dearth of necessary facilities and services (Tudela, 1995). Because of international immigration flows, several cultural groups currently live together in the neighbourhood, most prominently from the Pakistani community, who account for approximately $16 \%$ of the residents (Ajuntament de Badalona, 2015), and the Roma community. Badalona is one of the cities with the largest Roma populations in Catalonia (Sánchez Aroca, 2005). Other immigrant groups living there come from China, Ecuador, Bolivia, India, Romania, Colombia, Peru, Italy and Argentina (Serra \& Smilges, 2013). This neighbourhood 
began as a warren of shacks, the homes to migrants and cultural minorities who suffered from high unemployment rates and coexistence problems. Currently, victims of unemployment still live in the neighbourhood, and other circumstances still persist, such as crime, poverty, social exclusion and conflicts among people from other cultures. It is one of the 600 neighbourhoods with a high poverty rate in Spain (Ministerio de Fomento, 2006; Observatorio de la Vulnerabilidad Urbana, 2011).

The existing conflicts in the neighbourhood were known by both the press and the data on its high crime and exclusion rates, as were the facts that the main characters stated at the beginning of this study. These conflicts, focusing on the bonds among ethnic groups, had to do with theft and physical violence (Clemente, 2010; Requena, 2003).

Tio Antonio is a respected Roma who came to Badalona (initially in a shantytown called Somorrostro) with his family when he was little and has lived in the neighbourhood since 1964. Said is a member of the Pakistani community and also a reference within that community. Their friendship, at the time of the interview, dated back 9 years, when the mayor at the time called both of them to a meeting to talk about the problems in the neighbourhood and seek ways to solve them; the problems were conflicts associated with thefts, acts of violence among people from different cultural groups and other types of attacks. From then on, in situations of conflict in the neighbourhood, the two men would speak with each other and with the people involved to seek peaceful ways of solving them. This teamwork also led to a strong friendship between the two (as shall be seen in the Results section in this article).

\section{Methodology}

The communicative methodology (CM) was used in this case study (Gomez, Puigvert, \& Flecha, 2011). This methodology was recommended by the European Commission, especially for research with vulnerable groups and cultural minorities because of its impact on the social transformation it generates (European Commission, 2010; Puigvert, Christou, \& Holford, 2012). The foundation of CM is the creation of knowledge and the interpretation of reality via egalitarian dialogue between the researchers and the participants in the study based on their life 
experiences, thus overcoming the monopolisation of expert knowledge (Habermas, 1984). The outcome is the dialogic construction of knowledge with the incorporation of the voices of the participants throughout the entire process, which contributes to increasing the social usefulness of the results of the research (Gomez, 2014; Flecha \& Soler, 2013).

\section{Selection of Participants}

Some of the authors of this study were in contact with the different people involved in the study from the very start and involved in several of the activities held in the neighbourhood. The entire process spanned from July 2012 until June 2018. First, contact was made, the objectives and the methodology of the study were explained, and the written informed consent needed to conduct the fieldwork was obtained. At all times, the participants expressed their gratitude at being able to shine a spotlight on the positive aspects of their neighbourhood and how it is possible to show alternatives for more peaceful coexistence among ethnic groups in such vulnerable neighbourhoods.

The sample was chosen via natural groups, that is, people who already knew each other and tended to engage in activities together and are a natural part of life in the neighbourhood, in some cases because they live there and in others because they work there, and for these different reasons they know each other. This form of selection corresponds to the communicative methodology and can be summarised as follows: it is "composed of individuals who already know each other and meet in a context that is familiar to all the participants. For instance, a focus group could take place with a group of workers in their own workplace" (Gomez, Puigvert, \& Flecha, 2011, p. 240). 
Table 1

Participants in the study and characteristics

\begin{tabular}{l|l}
\hline \multicolumn{1}{c|}{ Participants* } & \multicolumn{1}{c}{ Brief description } \\
\hline Uncle Antonio & $\begin{array}{l}\text { Roma leader in Sant Roc neighbourhood and president of } \\
\text { the Association. }\end{array}$ \\
\hline Said & $\begin{array}{l}\text { Pakistani resident of Sant Roc neighbourhood, leader of } \\
\text { the Sunni Muslim community and vice president of the } \\
\text { Association. }\end{array}$ \\
\hline Police officer 1 & Regional police officer. \\
\hline Police officer 2 & Regional police officer. \\
\hline Police officer 3 & Head of the regional police. \\
\hline Tomas & Roma leader and member of the Association. \\
\hline Manolo & Roma and secretary of the Association. \\
\hline Laura & Daughter of Tio Antonio. \\
\hline Adelina & Wife of Tio Antonio. \\
\hline Antonia & Mother-in-law of Tio Antonio. \\
\hline Ángeles & Dominican, member of the board of the Association. \\
\hline Ibaa & Pakistani, member of the Shiite Muslim community. \\
\hline Khalid & Pakistani, member of the Shiite Muslim community \\
\hline María & $\begin{array}{l}\text { Former teacher and, member of the association of a } \\
\text { school. }\end{array}$ \\
\hline Raquel & Educator. \\
\hline José & Roma, member of the Association. \\
\hline
\end{tabular}

Note. All the names are pseudonyms to maintain the privacy of the participants.

\section{Data Collection}

The data collection instruments applied include two qualitative techniques: communicative life stories and communicative-oriented interviews. These techniques shall be briefly explained in the subsections below. They were all conducted within the period of one month. In the application of all the instruments, a communicative orientation was used based on intersubjective dialogue between the researcher and the participants since the objective was 
to create a joint interpretation of reality while creating knowledge about the case studied and its objectives and results (Gomez, Puigvert, \& Flecha, 2011). This set of techniques fosters the triangulation of results; in other words, they allow the data collected with each of them to be compared in order to bring greater validity and reliability to the study.

\section{Communicative daily life stories}

Communicative daily life stories are conversations that the researcher has with the person participating in the study. The objective of this technique is to be able to hear the participants' interpretation of their life stories through an egalitarian dialogue in which the researcher provides data and information to the study being carried out. The reflection and interpretation of this dialogue becomes the outcome of the technique (Gomez, Racionero, \& Sordé, 2010).

Given the objective of this article, only two communicative life stories of everyday life were made, specifically those of Tio Antonio and Said. The objectives were not only to further explore the origin and evolution of their friendship, but also to ascertain how it had changed their personal lives and impacted the neighbourhood by improving other relationships and the existing conflicts.

\section{Interviews}

To expand the information, a total of 16 interviews were held. Seven of the interviewees were from the Roma community, 3 from the Pakistani community, 1 from the Latin American community, 3 were police officers stationed in the neighbourhood, 1 was a former educator in the neighbourhood and 1 is currently a social educator at one of the neighbourhood's social entities. All of the interviewees know Tio Antonio and Said either directly or indirectly. The goal of these testimonials was to capture views of the transformations in the neighbourhood through the personal friendship between Tio Antonio and Said from other vantage points. 


\section{Data Analysis}

The categories chosen to analyse the fieldwork were personal friendship and transformation of the conflict. To analyse the "personal friendship" category, we used the definition of quality friendship outlined in section 2 of this article, while the "transformation of the conflict" category is associated with overcoming (or not) the conflicts that exist in excluded neighbourhoods and zones, as outlined in section 1 of this article.

In line with the methodology used in this study, the two categories and the data were analysed using the communicative methodology's twofold dimension of analysis: the exclusionary dimension and the transformative dimension (Gomez et al., 2011). In this study, the exclusionary dimension of the reality being studied refers to the barriers that hinder actions that foster conflict prevention and resolution in the Sant Roc neighbourhood. The transformative dimension includes the way these barriers are overcome, thus allowing the implementation of factors that enable conflictive relationships among cultures to be transformed into peaceful, constructive relationships. This analysis was conducted using the MAXQDA software.

\section{Results}

Our data show how the personal friendship between Said and Tio Antonio led to a transformation in the conflictive relations among cultures and to peaceful relations in the Sant Roc neighbourhood of Badalona. One hundred percent of the comments analysed from the communicative life stories and interviews relate their personal friendship with factors that allow for and foster the prevention and resolution of conflicts in the neighbourhood. It is noteworthy that there were no comments that related this personal friendship with exclusionary dimensions. Within the transformative dimension, two categories related to the context were detected, namely: the positive values of friendship, and the coherence between positive values and the actions taken. We shall now further explore these two, followed by an overview of all those data related to the reduction of conflicts and improvements of the living together there. 


\section{Positive values leading to mutual trust beyond them}

Twenty-five percent of the comments analysed in the fieldwork are related to the positive values embodied in this personal friendship. Specifically, they are related to values like respect, equality, cooperation, commitment, trust, loyalty, support and dialogue, all of which are essential for human beings.

On the one hand, we detected that the two men who have forged this friendship have a positive image of each other; in other words, they hold each other in esteem. Hence, they value each other. The following examples reveal this esteem and the value based on the comments they make. First Tio Antonio tells about the moment they met:

My friendship with Said... at a meeting with the mayor. She introduced Said. So what happened? I saw a very responsible man, and shortly after seeing him we had already become friends and we saw the problems in the neighbourhood and tried to solve them.

In a similar vein, Said explains his perception of Tio Antonio both when he met him and afterward:

I always say: I had the satisfaction and pleasure and I don't know what other word I can add... of meeting Tio Antonio. And so, we were only working for our community and... then I met Antonio and the fact is he's a very diplomatic person, just like other people around him.

In line with the friends' positive image of each other, through the field work it was also found that other people in their respective cultural communities and others in the neighbourhood have the same perception of Tio Antonio and Said. For example, Khalid, a Pakistani who has been living in the neighbourhood for over 8 years, tells us about the admiration he feels for Said and the work he does: "Said is a famous man in Badalona. Really people who are working for humanity." Furthermore, one of the police officers interviewed said the same but about Tio Antonio: "(Tio Antonio)... if he gives you his word... that this is white... it's white. And if tells you this guy is going to take you tomorrow, he's taking you tomorrow. 
That's happened to us. He's a great touchstone in the neighbourhood." (Police officer 2). This has led people to perceive the friends as similar. Laura, one of the Roma women in the neighbourhood, puts it this way: "They're the kind of men who are very compatible". The two friends are aware of the similarity in their values, and Tio Antonio mentions it this way in his story:

\begin{abstract}
We're similar in many ways (Said and himself) because Said works hard for his people, he works $100 \%$. You call him at one, at two, at three, at four in the morning. There's no schedule. And you can see this in a man who's engaged. And Said sees the same in me. You know, responsible people and so we give our all without asking for anything in return.
\end{abstract}

Everything has led not only the two friends but also the people in the neighbourhood to see how they have worked on this friendship and this mutual trust. This was mentioned by one of the three police officers interviewed: "They have both worked on trust. Mutual trust based on the conviction that they both end up winning" (Police officer 3).

\title{
Consistency between what they preach and what they do
}

Values, as mentioned above, are a beacon for the behaviour and actions of the two friends in Sant Roc neighbourhood. Sixty-five percent of the comments analysed in the fieldwork were directly related to the transformation of the neighbourhood, and $22 \%$ were associated with the friendship between Said and Tio Antonio. Thus, we find a correlation between the values in this friendship and the acts of the two friends. One of the police officers explains it as follows:

It is incredible that through an aggression we had with a Pakistani individual here in Sant Roc neighbourhood, we held this meeting and these reflections and from there the need to do something emerged. At that meeting... those who realised that something had to be done were the natural leaders: Said and Tio Antonio (Police officer 3 ). 
Likewise, the data reveal that the two friends have a shared objective: to improve their neighbourhood. Following this analysis, it was detected that both Said and Tio Antonio pour all their energy and knowledge into making this happen.

The natural leaders take, within their resources, their low educational level, but with all the energy in the world and with their leadership... what occurred to them is to create this Intercultural Association to become the mechanism through which the young people meet each other, because if the young people meet it's easier for there to be more loyalty and more friendships later... (Police officer 3).

Based on this coherence between their values and actions, an Intercultural Residents' Association was created in Badalona with the goal of improving the neighbourhood, with an emphasis on peaceful coexistence. Tomás, one of the leaders of the Roma community and a resident of the neighbourhood, tells us below how the dialogue between Said and Tio Antonio has led this intercultural association to grow with the purpose of working and improving the coexistence in Sant Roc neighbourhood:

Two ways of solving conflicts: either violence or dialogue. All of them, but especially those two, Antonio and Said. On the other hand, finding natural leaders, known and respected, not legal but legitimate, each with their own, and Antonio with us, and this gives them and it gives us representativeness in the neighbourhood, multiculturalism of the police and everyone. Of course, after all this work instead of being somewhat free we've made it more legal and about unification, and this is going to have a major impact and it's going to have a heavy impact (Tomás).

\section{A Friendship that transforms}

In line with friendship based on positive values and the actions that both friends are undertaking in Sant Roc, very positive consequences are appearing which are helping improve coexistence in the neighbourhood. Some of these can be summarized by four distinctive aspects. 
The first one was the eradication of long-standing stereotypes among both communities. Members of the different communities explained how stereotypes have been eliminated through this interaction based on friendship. Tomás, a Roma leader, put it this way: "Stereotypes have been broken, now we go have a coffee together... stereotypes have been broken" (Tomás).

Second one consists in feeding other friendships among people from different religions and cultures. Previously, some neighbourhood residents already had relationships with people from different cultures, but after the friendship between the leaders of the Pakistani and Roma communities, more friendships emerged. Ibaa, a member of the Pakistani community, said the following:

We have shown that we can interact with each other. We have tactically shown that we can have strong relationships with any religion. We have no issues. We're great together even though we're totally different. (Ibaa)

Manolo, a member of the Roma community, said:

We have (Pakistani) friends, not just one but several. They're really good people. The idea is for them to get to know us and us to get to know them. And since we have to live together in the neighbourhood, we have to get along better. (Manolo).

Similarly, this friendship also sparked more friendships among women from different communities. Laura, a Roma woman, recounted:

Religions should not separate us, one woman from another... I have friends of all kinds, I have Moroccan friends, Pakistani friends, friends from India... from here in the neighbourhood. I have a bit of everything, the best from each culture. So I'm multicultural. (Laura).

Therefore, a third element that need to be distinguished is the reduction in conflicts in the neighbourhood. Both the community members and the 
police officers note that there has been a decrease in conflict. This is how the different police officers expressed it:

The community police have noticed that Said, a Pakistani representative, and $\mathrm{Mr}$ Cortés (Tio Antonio), a Roma representative, have together managed to repress their communities so that the conflicts which might arise have not gotten worse" (Police officer 1).

Crime in the neighbourhood has dropped considerably, I mean a lot" (Police officer 2).

Finally, the last but not least element is the e creation of spaces of dialogue. As mentioned above, the creation of the Intercultural Residents' Association of Badalona is generating spaces of encounter and dialogue among the different people living in the neighbourhood. This is helping them get to know each other and create new friendships.

What happened with this organisation is that there is more respect, we get along better, there is more dialogue. What happened the other day. I'd never seen it before, a match was being played with different ethnic groups and there were no arguments. That used to be impossible (Tio Antonio).

In short, Tio Antonio summarises the results obtained from the personal friendship between him and Said in this way: "We are achieving this... Eliminating the violence and making us all friends" (Tio Antonio).

\section{Concluding Remarks}

This study demonstrates that personal friendship, specifically the friendship between Said and Tio Antonio, bears a huge influence on transforming conflictive relationships in neighbourhoods, especially in those at the risk of social exclusion. The friendship between the two men has eliminated the stereotypes between the Roma and Pakistani communities, increased friendships between the communities, reduced the conflicts in the neighbourhood and created spaces of dialogue. Thus, quality personal 
friendships, as posited by Berndt (1996) and Bukowski, Motzoi, and Meyer (2009), can play a major role in mediating conflicts.

Based on these results, we could say that in order for there to be an improvement in neighbourhoods via personal friendships like those presented in this article, two elementary features must be in place: first, there must be values that foster mutual wellbeing among the friends, such as solidarity, cooperation, loyalty, commitment, trust, dialogue and others. Secondly, the actions must be coherent with these values. Therefore, as DeScioli and Kurzban (2009) state, the choice of friends is essential; in other words, our moral values have to be positive and in line with our friendships. Furthermore, if these values are mutual and beneficial for each friend, they transform into actions and can generate social change.

Likewise, this study demonstrates, as previous studies have, that it is possible to establish a fully trusting, loyal relationship with people from different cultures and religions. At the same time, it reveals that having a shared objective and forging a dialogue with people from different communities is crucial to peaceful coexistence and the construction of personal intercultural friendships.

In short, personal friendship based on positive values and the actions that stem from them makes it possible to transform conflictive relationships among cultures into peaceful, constructive relationships. This is why friendship is one of the cornerstones in improving coexistence, especially among different cultures, and amidst highly vulnerable social conditions.

\section{Notes}

${ }^{1}$ Law no. 10,639/03 was amended by Law no. 11,645/08 of March 10, with the introduction of compulsory teaching of history and culture of indigenous peoples.

\section{References}

Ainscow, M., \& Miles, S. (2009). Developing Inclusive Education Systems: How Can We Move Policies Forward? Manchester, UK: University of Manchester.

Ajuntament de Badalona (2015, January). Nacionalidad de la Población por División Territorial de la Ciudad de Badalona. Retrieved from http://opendata.badalona.cat/badalona/es/catalog/POBLACIO 
80 Villarejo-Carballido, et al. - The power of friendship in Sant Roc

Allport, G. W. (1954). The Nature of Prejudice. New York: Doubleday Anchor Books.

Asher, S. R., Parker, J. G., \& Walker, D. L. (1996). Distinguishing friendship from acceptance: Implications for intervention and assessment. In W. M. Bukowski, A. F., Newcomb, \& W. W. Hartup (Eds.), Cambridge studies in social and emotional development. The company they keep: Friendship in childhood and adolescence (pp. 366-405). New York, NY, US: Cambridge University Press.

Aydin, N., Krueger, J. I., Frey, D., Kastenmuller, A., \& Fischer, P. (2013).

Social Exclusion and Xenophobia: Intolerant Attitudes Toward Ethnic and Religious Minorities. Group Processes \& Intergroup Relations, 17(3), 371-387. doi: 10.1177/1368430213510569

Berndt, T. J. (1996). Transitions in Friendship and Friends' Influence. In J. A. Garber, J. Brooks-Gunn \& A. C. Petersen (Eds.), Transitions

Through Adolescence: Interpersonal Domains in Context (pp. 5784). Mahwah, NJ: Lawrence Erlbaum Associates.

Bilge, N. (2019). Friend or Foe: Cultural Fusion Theory and Media Coverage of Syrian Refugees in Turkey. Communication Culture \& Critique, 12(1), 110-127.

Blank, M. J., Melaville, A., \& Shah, B. P. (2003). Making the Difference:

Research and Practice in Community Schools. Washington:

Coalition for Community Schools.

Blieszner, R.H., \& Adams, R.G. (1992). Adult Friendship. California: Sage Publications.

Boyle, M. H., Georgiades, K., Duncan, L., Wang, L., Comeau, J., \& 2014 Ontario Child Health Study Team. (2019). Poverty, Neighbourhood Antisocial Behaviour, and Children's Mental Health Problems: Findings from the 2014 Ontario Child Health Study. The Canadian Journal of Psychiatry, 64(4), 285-293. doi:

$10.1177 / 0706743719830027$

Bukowski, W. M., Motzoi, C., \& Meyer, F. (2009). Friendship as process, function, and outcome. In K. H. Rubin, W. M. Bukowski, \& B. Laursen (Eds.), Social, emotional, and personality development in context. Handbook of peer interactions, relationships, and groups (pp. 217-231). New York, NY, US: Guilford Press. 
Clemente, E. (2010, November 26). Badalona, un laboratorio explosivo. La Voz de Galicia. Retrieved from

https://www.lavozdegalicia.es/noticia/espana/2010/11/26/badalonalaboratorio-explosivo/0003_8872807.htm

Cole, W. M. (2018). Poor and powerless: Economic and political inequality in cross-national perspective, 1981-2011. International Sociology, 33(3), 357-385. doi: https://doi.org/10.1177/0268580918760430

Demir, M., Şimşek, Ö. F., \& Procsal, A. D. (2012). I Am so Happy 'Cause My Best Friend Makes Me Feel Unique: Friendship, Personal Sense of Uniqueness and Happiness. Journal of Happiness Studies, 14(4), 1201-1224. doi: 10.1007/s10902-012-9376-9

DeScioli, P., \& Kurzban, R. (2009). The Alliance Hypothesis for Human Friendship. PLoS ONE, 4(6), e5802.

doi:10.1371/journal.pone.0005802

European Commission. (2010). Combating poverty and social exclusion. a statistical portrait of the European Union 2010. Luxembourg: Publications Office of the European Union.

EuroStat. (2020, January). People at risk of poverty or social exclusión.

Retrieved from https://ec.europa.eu/eurostat/statisticsexplained/index.php/People_at_risk_of_poverty_or_social_exclusion Flecha, R., \& Soler. M. (2013). Turning Difficulties into Possibilities: Engaging Roma families and Students in School through Dialogic Learning. Cambridge Journal of Education, 43(4), 451-465. doi: https://doi.org/10.1080/0305764X.2013.819068

Frankenberg, E., \& Orfield, G. (2007). Lessons in Integration: Realizing the Promise of Racial Diversity in American Schools. Cambridge: The Civil Rights Project at Harvard University.

Fundación FOESSA, \& Caritas España. (2013). Desigualdad y derechos sociales: Análisis y perspectivas. Fundación FOESSA. Retrieved from

http://www.caritas.es/imagesrepository/CapitulosPublicaciones/4551/ Desigualdad\%20y\%20derechos\%20sociales.\%20Versión\%20digital. pdf

Fundación FOESSA \& Caritas. (2014). VII Informe sobre exclusión y desarrollo social en España. Retrieved from 
82 Villarejo-Carballido, et al. - The power of friendship in Sant Roc

http://www.foessa2014.es/informe/uploaded/descargas/VII_INFOR ME.pdf.

García-Carrión, R., Molina-Luque, F., \& Roldán, S. M. (2018). How do vulnerable youth complete secondary education? The key role of families and the community. Journal of Youth Studies, 27(14), 701716. doi: 10.1080/13676261.2017.1406660

García-Espinel, T., Santiago-Santiago, L., \& García-Algar, M. (2019).

Diseñando e Implementado Políticas Públicas con y para la Comunidad Gitana. El Impacto Social del Plan Integral del Pueblo Gitano en Cataluña. International Journal of Roma Studies, 1(1), 84119. doi: http://dx.doi.org/10.17583/ijrs.2019.3957

Gereluk, D., \& Race, R. (2007). Multicultural Tensions in England, France and Canada: Contrasting Approaches and Consequences.

International Studies in Sociology of Education, 17(1-2), 113-129. doi: 10.1080/09620210701433837

Giner, E. (2018). Amistad Deseada. Barcelona: Hipatia Editorial.

Girbés-Peco, S., Renta, A.I., De Botton, L., \& Álvarez, P. (2018). The

Montserrat's neighbourhood dream: involving Moroccan residents in a school-based community development process in urban Spain.

Social \& Cultural Geography,(Published online). doi: 10.1080/14649365.2018.1509112

Gomez, A. (2014). How Friendship Generates Key Research Questions That Help to Overcome Gender-Based Violence A Personal Narrative. Qualitative Inquiry, 20(7), 934-940. doi: /10.1177/1077800414537220

Gomez, A., Puigvert, L., \& Flecha, R. (2011). Critical communicative methodology: informing real social transformation through research. Qualitative Inquiry 17(3), 235-245. doi: 10.1177/1077800410397802

Gomez, A., Racionero, S., \& Sordé, T. (2010). Ten years of critical communicative methodology. International Review of Qualitative Research, 3(1), 17-43. doi: 0.1525/irqr.2010.3.1.17

Greene, J. (2014). Managing Poverty, Managing Dissent: Homeless Politics and Collective Action in London. Policy \& Politics, 42(3), 315-331. doi: http://dx.doi.org/10.1332/030557312X655936 
Habermas, J. (1984). The theory of communicative action. V. 1. Reason and the rationalization of society. Boston, MA: Beacon Press.

Harper, G. W., Dolcini, M. M., \& Benhorin, S. (2014). The Benefits of a Friendship-Based HIV/STI Prevention Intervention for African

American Youth. Youth \& Society, 46(5), 591-622. doi:

10.1177/0044118X12444210

Hartup, W. W., \& Stevens, N. (1999). Friendships and Adaptation Across the Life Span. Current Directions in Psychological Science, 8(3), 76-79. doi: 10.1111/1467-8721.00018

Hassan, H. M. (2015). Extraordinary Politics of Ordinary People:

Explaining the Microdynamics of Popular Committees in Revolutionary Cairo. International Sociology, 30(4), 383-400. doi: $10.1177 / 0268580915585238$

Ho, K.H., \& Chua, V. (2017). The neighbourhood roots of social cohesion: Notes on an exceptional case of Singapore. Environment and Planning C: Politics and Space, 36(2), 290-312. doi: $10.1177 / 2399654417710659$

Housing Europe Observatory. (2018). Housing \& Migration. Research briefing. Brussels: European Comission. Retrieved from http://www.housingeurope.eu/resource-1179/pathways-to-socialinclusion

Human Rights Watch (2014). World Report 2014: European Union. Retrieved from http://www.hrw.org/es/world-report/2014/countrychapters/121983

Jones, R. M., Vaterlaus, J. M., Jackson, M. A., \& Morrill, T. B. (2014). Friendship Characteristics, Psychosocial Development, and Adolescent Identity Formation. Personal Relationships, 21(1), 5167. doi: 10.1111/pere. 12017

Lee, P. W. (2006). Bridging cultures: Understanding the construction of relational identity in intercultural friendship. Journal of Intercultural Communication Research, 35(1), 3-22. doi: https://doi.org/10.1080/17475740600739156

MacDonald, R., Shildrick, T., Webster, C., \& Simpson, D. (2005). Growing up in poor neighbourhoods: The significance of class and place in the extended transitions of 'socially excluded'young 
84 Villarejo-Carballido, et al. - The power of friendship in Sant Roc

adults. Sociology, 39(5), 873-891. doi:

https://doi.org/10.1177/0038038505058370

Matsaganis, M., \& Leventi, C. (2014). The Distributional Impact of

Austerity and the Recession in Southern Europe. South European

Society and Politics, 19(3), 393-412. doi

$10.1080 / 13608746.2014 .947700$

Meleady, R., \& Vermue, M. (2019). The effect of intergroup contact on solidarity-based collective action is mediated by reductions in SDO. Journal of Applied Social Psychology, 49(5), 307-318. doi: https://doi.org/10.1111/jasp.12586

Millen, K., Dorn, B., \& Luckner, J. L. (2019). Friendships and SelfDetermination Among Students Who Are Deaf or Hard of Hearing. American annals of the deaf, 163(5), 576-595. doi: 10.1353/aad.2019.0004

Ministerio de fomento. (2006). Informe de Descripción Urbanística.

Gobierno de España Retrieved from

http://habitat.aq.upm.es/bbvv/fichas/2006/fu-

barrios/fu06_08015001.pdf

Morrison, N. (2003). Neighbourhoods and Social Cohesion: Experiences from Europe. International Planning Studies, 8(2), 115-138. doi: $10.1080 / 13563470305154$

Nicolae, V. (2006). Towards a Definition of Anti-Romaism. Brussels:

ERGO Network.

Observatorio de la Vulnerabilidad Urbana. (2011). Atlas de la

Vulnerabilidad Urbana. Retrieved from

http://atlasvulnerabilidadurbana.fomento.es/

Organización de Consumidores y Usuarios (OCU). (2012). Informe de

Calidad de Vida de las Ciudades: Ha empeorado. Retrieved from http://www.ocu.org/consumo-familia/nc/informe/calidad-ciudades/5

Peruzzi, A. (2014). From Childhood Deprivation to Adult Social Exclusion: Evidence from the 1970 British Cohort Study. Social Indicators Research, 120(1), 117-135. doi: https://doi.org/10.1007/s11205-0140581-2

Pettigrew, T. F., \& Tropp, L. R. (2008). How Does Intergroup contact reduce prejudice? Meta-analytic tests of three mediators. European Journal of Social Psychology, 38(6), 922-934. doi: 10.1002/ejsp.504 
Puigvert, L., Christou, M., \& Holford, J. (2012). Critical communicative methodology: including vulnerable voices in research through dialogue. Cambridge Journal of Education, 42, 513-526. doi: 10.1080/0305764XX.2012.733341

Ramis, M.M. (2018). Contributions of Freire's Theory to Dialogic Education. Social and Education History, 7(3), 277-299. doi: http://dx.doi.org/10.17583/hse.2018.3749

Requena, J. (2003). "La peor casa en el peor barrio". Barrios de inmigración y marginalidad en la periferia urbana de Barcelona. El caso de Badalona. Scripta Nova, 146(058). Retrieved from http://www.ub.edu/geocrit/sn/sn-146(058).htm

Rusch, D., Frazier, S. L., \& Atkins, M. (2015). Building capacity within community-based organizations: new directions for mental health promotion for latino immigrant families in urban poverty.

Administration and Policy in Mental Health, 42(1), 1-5. doi: 10.1007/s10488-014-0549-1

Serra, P., \& Smilges, A. (2013). Effects of the Economic Crisis on the Foreign Population in the Municipality of Badalona in 2010. Revista Interdisciplinar de Ciências Sociais e Humanas, 1(1), 488-520. doi: 10.3989/estgeogr.201323

Saegert, S., Thompson, P., \& Warren, M. R. (2002). The Role of Social Capital in Combating Poverty. En S. Saegert, P. Thompson y M. R. Warren (Eds.), Social Capital and Poor Communities (pp. 1-30). Russell Sage Foundation: New York.

Sánchez Aroca, M. (2005). Estudi sobre la población gitana de Catalunya. Barcelona: Generalitat de Catalunya. Retrieved from http://treballiaferssocials.gencat.cat/web/.content/01departament/08p ublicacions/ambits_tematics/serveis_socials/08estudipoblaciogitanac at05/2005estudipoblaciogitanacat.pdf

Save the Children (2014). Child Poverty and Social Exclusion in Europe. Save the Children. Retrieved from

https://resourcecentre.savethechildren.net/sites/default/files/documen ts/child-poverty-and-social-exclusion-in-europe-low-res.pdf

Silk, J. B. (2003). Cooperation withouth counting. The puzle of

Friendsship. In P. Hammerstein (Ed), Genetic and cultural evolution of cooperation. (pp. 37-54). Boston:MIT Press. 
86 Villarejo-Carballido, et al. - The power of friendship in Sant Roc

Talaslampi, H., Jahnukainen, M., \& Manninen, M. (2019). The factors that contribute educational outcomes of adolescents placed in care due to severe behavioral problems. Children and Youth Services

Review, 102, 210-221. doi:

https://doi.org/10.1016/j.childyouth.2019.05.021

Taylor, J. J., Grant, K. E., Amrhein, K., Carter, J. S., Farahmand, F., Harrison, A., Thomas, K., Carleton, R., Lugo-Hernandez, E., \& Katz, B. N. (2014). The Manifestation of Depression in the Context of Urban Poverty: A Factor. Psychological Assessment, 26(4), 1317-32. doi: $10.1037 / \mathrm{a} 0037435$

Tooby, J., \& Cosmides, L. (1996). Friendship and the Banker's Paradox: Other Pathways to the Evolution of Adaptations for Altruism. Proceedings of the British Academy, 88, 119-143. Retrieved from https://pdfs.semanticscholar.org/1bf4/f9c7c3b3d6149fae4c8a9c0621f 2ccc2e072.pdf

Tilly, L. (2012). Having friends-they help you when you are stuck from money, friends and making ends meet research group. British Journal of Learning Disabilities, 40(2), 128-133.

doi: 10.1111/j.1468-3156.2012.00739.x

Tudela, J. (1995). Sant Roc. Badalona (Els barris d'ADIGSA). Barcelona: Generalitat de Catalunya.

UN. (2012). World Urbanisation Prospects: The 2011 Revision, Data Tables and Highlights. Retrieved from

https://www.un.org/en/development/desa/population/publications/pdf /urbanization/WUP2011_Report.pd

Wilson W. J. (1996). When Work Disappears: The World of the New Urban Poor. New York: Random House.

Wong, H. (2006). Human capital, social capital and social exclusion: Impacts on the opportunity of households with youth to leave poverty. International Journal of Adolescent Medicine and Health, 18(3), 521-534. Retrieved from https://web.swk.cuhk.edu.hk/ hwong/pubfile/journal/2006_Human_ Capital_Social_Capital_and_Social_Exclusion_IJAMH.pdf 
Beatriz Villarejo-Carballido is "Juan de la Cierva" Postdoctoral researcher in the Faculty of Psychology and Education at the University of Deusto (Spain)

Carme García Yeste is senior professor and researcher in the Faculty of Education at the University Rovira i Virgili (Spain)

Maria del Mar Ramis is associated professor in the Department of Sociology at the University of Barcelona (Spain).

Laura Ruíz-Eugenio is "Ramón y Cajal" Post-doctoral researcher in the Faculty of Education at the University of Barcelona (Spain)

Contact address: breatriz.villarejo@ deusto.es 